\title{
Correction to: Repository corticotropin injection versus corticosteroids for protection against renal damage in a focal segmental glomerulosclerosis rodent model
}

Kyle Hayes, Elizabeth Warner, Chris Bollinger, Dale Wright and Richard M. Fitch

Correction to: BMC Nephrology (2020) 21:226

https://doi.org/10.1186/s12882-020-01879-6

Following publication of the original article [1], the authors identified an error in Fig. 7. The correct figure is given below.

The original article has been corrected.

Published online: 16 July 2020

\section{Reference}

1. Hayes $\mathrm{K}$, et al. Repository corticotropin injection versus corticosteroids for protection against renal damage in a focal segmental glomerulosclerosis rodent model. BMC Nephrol. 2020;21:226. https://doi.org/10.1186/s12882020-01879-6.

The original article can be found online at https://doi.org/10.1186/s12882020-01879-6.

* Correspondence: Kyle.Hayes@mnk.com

Mallinckrodt Pharmaceuticals, 675 James S. McDonnell Blvd, 20-1-W,

Hazelwood, MO, USA

C C The Author(s). 2020 Open Access This article is licensed under a Creative Commons Attribution 4.0 International License, which permits use, sharing, adaptation, distribution and reproduction in any medium or format, as long as you give appropriate credit to the original author(s) and the source, provide a link to the Creative Commons licence, and indicate if changes were made. The images or other third party material in this article are included in the article's Creative Commons licence, unless indicated otherwise in a credit line to the material. If material is not included in the article's Creative Commons licence and your intended use is not permitted by statutory regulation or exceeds the permitted use, you will need to obtain permission directly from the copyright holder. To view a copy of this licence, visit http://creativecommons.org/licenses/by/4.0/ The Creative Commons Public Domain Dedication waiver (http://creativecommons.org/publicdomain/zero/1.0/) applies to the data made available in this article, unless otherwise stated in a credit line to the data. 


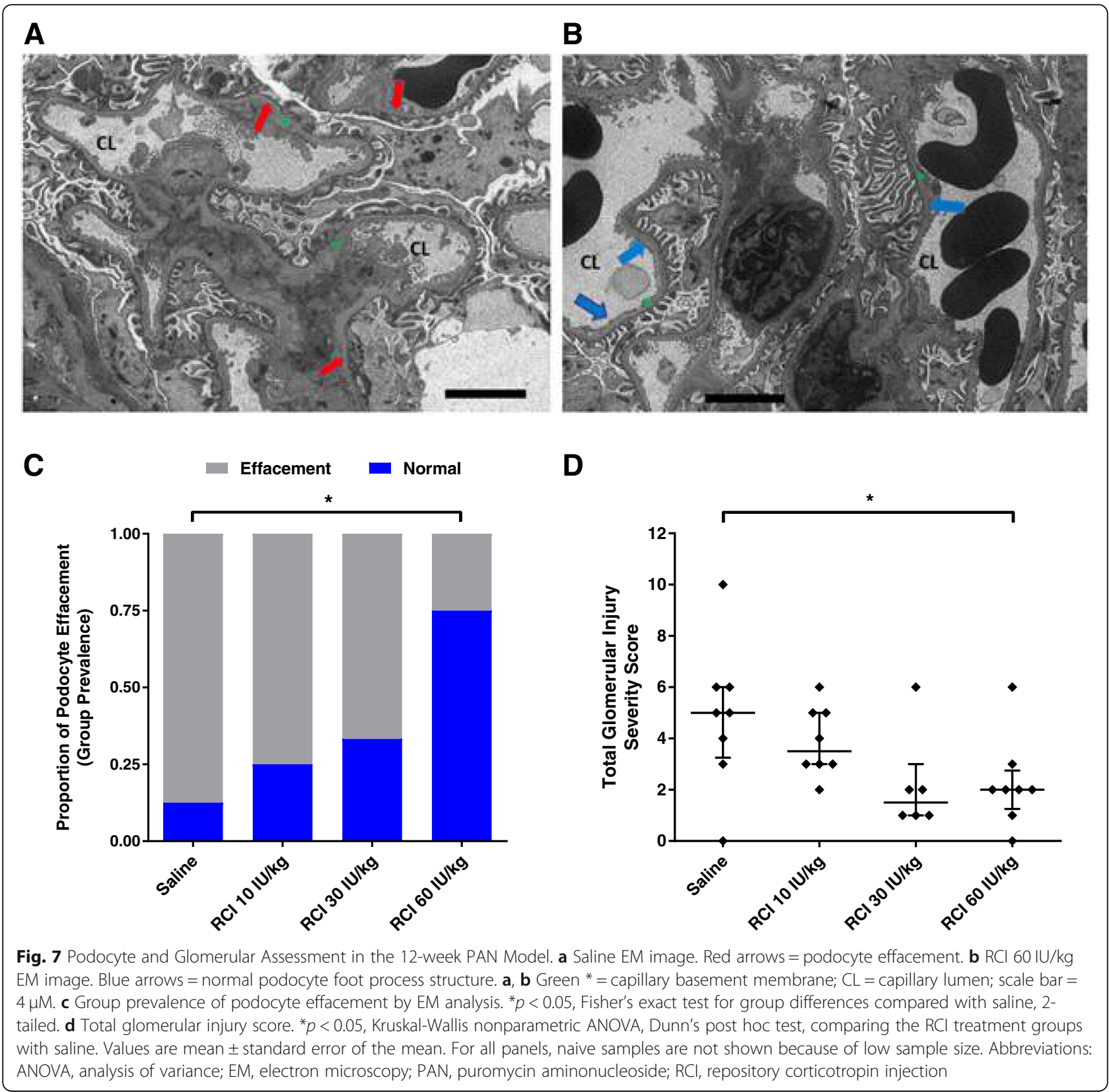

